\title{
Electrical and Optical Properties of Transparent Conducting Homologous Compounds in the Indium-Gallium-Zinc Oxide System
}

\author{
Toshihiro Moriga, ${ }^{*}, \dagger$ Daniel R. Kammler, ${ }^{*}$ and Thomas O. Mason ${ }^{*}$ \\ Department of Materials Science and Engineering and Materials Research Center, Northwestern University,
} Evanston, Illinois 60208

\section{George B. Palmer and Kenneth R. Poeppelmeier ${ }^{\star}$}

Department of Chemistry and Materials Research Center, Northwestern University, Evanston, Illinois 60208-3113

\begin{abstract}
The homologous compounds $\operatorname{In}_{1-x} \mathrm{Ga}_{1+x} \mathrm{O}_{3}(\mathrm{ZnO})_{k}$ (where $k=1,2$, or 3 ) were prepared at a temperature of $1400^{\circ} \mathrm{C}$. The solubility limits (as determined via $\mathrm{X}$-ray diffractometry) were $0.47<[\operatorname{In}] /([\mathrm{In}]+[\mathrm{Ga}])<0.67$ for the $k=1$ member, $0.35<[\operatorname{In}] /([\mathrm{In}]+[\mathrm{Ga}])<0.77$ for the $k=2 \mathrm{mem}-$ ber, and $0.29<[$ In $] /([\operatorname{In}]+[\mathrm{Ga}])<1.00$ for the $k=3$ member. Four-point-conductivity and diffuse-reflectance measurements were performed on as-fired and reduced samples. The band gap that was determined from diffuse reflectance increased as the $\mathrm{Ga}^{3+}$ content increased and $\boldsymbol{k}$ decreased. The conductivity increased as $k$ decreased and the $\operatorname{In}^{3+}$ content increased. A maximum conductivity of $250 \mathrm{~S} / \mathrm{cm}$ was obtained for $k=3$ and $[\operatorname{In}] /([\mathrm{In}]+[\mathrm{Ga}])=1$ after reduction. The minimum absorption edge of $325 \mathrm{~nm}$ was obtained for $k=2$ and $[\mathrm{In}] /([\mathrm{In}]+[\mathrm{Ga}])=0.35$ prior to reduction. The potential for metastable phases in the In-Ga-Zn-O system with enhanced transparent-conducting properties has been discussed.
\end{abstract}

\section{Introduction}

$\mathrm{T}$ RANSPARENT conducting oxides (TCOs) are used in a wide variety of applications, such as flat-panel displays, smart windows, and solar cells. Tin-doped indium oxide (ITO) is the commercial TCO of choice. ITO thin films exhibit conductivities of 1000-5000 S/cm and have $85 \%-90 \%$ transparency in the visible-wavelength range. ${ }^{1}$ Alternative materials with higher conductivity, better transparency at blue-green wavelengths, and lower cost are desired for use in demanding applications such as next-generation flat-panel displays. Recently, several highly transparent and conductive compounds in the $\mathrm{ZnO}-\mathrm{In}_{2} \mathrm{O}_{3}$ system have been prepared in thin-film form. Wang et al. ${ }^{2}$ reported a conductivity of $1100 \mathrm{~S} / \mathrm{cm}$ for sputtered $\mathrm{ZnO}$ films that contained $<5$ at. $\%$ indium. Minami and coworkers ${ }^{3,4}$ reported a conductivity of $2900 \mathrm{~S} / \mathrm{cm}$ for $\mathrm{Zn}_{2} \mathrm{In}_{2} \mathrm{O}_{5}$ films sputtered from polycrystalline targets that contained 10 60 at.\% zinc. In studies of pulsed-laser-deposited tin-doped

B. A. Tuttle-contributing editor

\footnotetext{
Manuscript No. 189911. Received August 31, 1998; approved April 5, 1999.

Supported by the MRSEC program of the National Science Foundation (under Contract No. DMR-9632472) at the Materials Research Center (MRC) of Northwestern University. This research used the Central Facilities the MRC of Northwestern University, which is supported by the same MRSEC program. Author TM, while on sabital at Northwestern University, was supported by a Research Fellowship from sabbatical at Northwe supported by a National Defense Science and Engineering Graduate Fellowship that was funded by the U.S. Office of Naval Research.

${ }^{*}$ Member, American Ceramic Society.

Permanent address: Department of Chemical Science and Technology, Faculty of Engineering, Tokushima University, 2-1 Minami-Josanjima, Tokushima 770-8506, Japan.
}

films, Phillips et al. ${ }^{5}$ reported conductivities as high as 2500 $\mathrm{S} / \mathrm{cm}$ for films with a $[\mathrm{Zn}] /([\mathrm{In}]+[\mathrm{Sn}])$ ratio of 0.5-0.6.

We previously reported the bulk $\mathrm{ZnO}-\mathrm{In}_{2} \mathrm{O}_{3}$ phase diagram and measured the physical properties of the homologous compounds, $\mathrm{Zn}_{k} \operatorname{In}_{2} \mathrm{O}_{3+k}$ (where $k=3,4,5,7,11$ ). The conductivity increased and the transparency decreased for lower- $k$ members. ${ }^{6}$ The $\mathrm{Zn}_{k} \mathrm{In}_{2} \mathrm{O}_{k+3}$ compounds belong to space group $R \overline{3} m$ with $z=3$ ( $z$ is the number of formula units per unit cell ${ }^{6}$ ) when $k$ is odd and space group $P 6_{3} / m m c$ with $z=2$ when $k$ is even. Kasper ${ }^{7}$ formed the $k=2,3,4,5$, and 7 members of the series in the temperature range of $1100^{\circ}-1550^{\circ} \mathrm{C}$ but was unable to form the $k=1$ member at temperatures up to $1740^{\circ} \mathrm{C}$. The exact structures of these compounds are unresolved. In a model that was proposed by Cannard and Tilley, ${ }^{8} k(0001)$ planes of $\mathrm{ZnO}$, which has the hexagonal wurtzite structure (space group $P 6_{3} m c$ ), are sandwiched between two (111) planes of $\operatorname{In}_{2} \mathrm{O}_{3}$, which has the cubic bixbyite crystal structure (space group Ia3). Kimizuka et al. ${ }^{9}$ proposed that these compounds are isostructural with $\mathrm{LuFeO}_{3}(\mathrm{ZnO})_{k}$, which has space group $R \overline{3} m$ for odd $k$ values and space group $P 6_{3} / m m c$ for even $k$ values. McCoy et al. ${ }^{10}$ attempted to resolve this structural question by comparing the two models, using atomistic simulation in combination with high-resolution electron microscopy (HREM), and concluded that, although both models seemed to give a good match to their simulations, the structure that was proposed by Cannard and Tilley ${ }^{8}$ gave the best fit.

Nakamura et al. ${ }^{11-13}$ also investigated homologous compounds $\mathrm{InMO}_{3}(\mathrm{ZnO})_{k}$ (where $\mathrm{M}=\mathrm{Fe}, \mathrm{Ga}$, or $\mathrm{Al}$ ) that they believed were also isostructural with $\mathrm{LuFeO}_{3}(\mathrm{ZnO})_{k}$. These compounds are believed to consist of equal numbers of $\mathrm{InO}_{2}^{-}$ and $\left(\mathrm{MZn}_{k}\right) \mathrm{O}_{k+1}^{+}$layers. The $\mathrm{In}^{3+}$ cation is believed to be octahedrally coordinated within the $\mathrm{InO}_{2}^{-}$layers, whereas the $\mathrm{M}^{3+}$ and $\mathrm{Zn}^{2+}$ cations occupy distorted trigonal-bipyramidal and tetrahedral sites within the $\left(\mathrm{MZn}_{k}\right) \mathrm{O}_{k+1}^{+}$layers. The extent of the single-phase regions that were obtained by changing the $[\mathrm{In}] /([\mathrm{In}]+[\mathrm{M}])$ ratio was investigated for $\mathrm{M}=\mathrm{Ga}$ for $k=$ $1-9,11$, and $13 .{ }^{12}$ For $k$ values of $\geq 3$, a complete solid solution for a $[\mathrm{In}] /([\mathrm{In}]+[\mathrm{Ga}])$ range of $0.5-1$ with the corresponding intergrowth, $\mathrm{In}_{2} \mathrm{O}_{3}(\mathrm{ZnO})_{k}$, was observed; however, the $k=1$ and $k=2$ compounds did not exhibit a complete solid solution to the $\mathrm{ZnO}-\mathrm{In}_{2} \mathrm{O}_{3}$ binary. ${ }^{12}$ Solid solutions for $[\mathrm{In}] /([\mathrm{In}]+[\mathrm{Ga}])$ in the range of $0-0.5$ also were observed for all $k$ values; however, none of these solutions extended to the $\mathrm{ZnO}-$ $\mathrm{Ga}_{2} \mathrm{ZnO}_{4}$ binary. ${ }^{12}$

Although a substantial amount of work has been performed to examine the crystal structure of these intergrowth phases, not much electrical conductivity and optical data for these materials exist. It has been previously shown that the conductivity increases as $k$ decreases for $[\mathrm{In}] /([\mathrm{In}]+[\mathrm{Ga}])=1 .{ }^{6}$ Pure indium $([\mathrm{In}] /([\mathrm{In}]+[\mathrm{Ga}])=1)$ compositions cannot be made for $k=1$ or 2 at $1400^{\circ} \mathrm{C}$; therefore, the possibility of producing highconductivity $k=1$ and $k=2$ compounds with gallium substituted for indium was the motivation for the present study. In 
this paper, we report the solubility limits, electrical conductivity, and absorption edge of single-phase $\mathrm{In}_{1-x} \mathrm{Ga}_{1+x} \mathrm{O}_{3}(\mathrm{ZnO})_{k}$ for $k=1,2$, and 3 in the $\mathrm{ZnO}-\mathrm{In}_{2} \mathrm{O}_{3}-\mathrm{Ga}_{2} \mathrm{O}_{3}$ system. The behavior of the electrical conductivity and band gap of these materials is related to their crystal structure.

\section{Experimental Procedure}

Table I describes samples of composition $\operatorname{In}_{1-x} \mathrm{Ga}_{1+x} \mathrm{O}_{3}$ $(\mathrm{ZnO})_{k}(k=1,2,3)$ that were prepared from $\mathrm{ZnO}(>99.9 \%$ purity, cation basis), $\mathrm{In}_{2} \mathrm{O}_{3}(>99.99 \%$ purity, cation basis), and $\mathrm{Ga}_{2} \mathrm{O}_{3}$ powders (>99.99\% purity, cation basis). The source of each of these powders was Aldrich Chemical Co. (Milwaukee, WI). The dried starting powders were ground under acetone in an agate mortar and pestle. The mixed powders were calcined at $1000^{\circ} \mathrm{C}$ overnight in air and then reground. Half-inchdiameter pellets were dry-pressed at $100 \mathrm{MPa}$. These pellets were buried in beds of their constituent powders (to limit contamination from the crucible and vaporization of $\mathrm{ZnO}$ and $\mathrm{In}_{2} \mathrm{O}_{3}$ ) and fired in covered alumina crucibles. The samples were quenched in air after $3 \mathrm{~d}$ at $1400^{\circ} \mathrm{C}$. Samples near a phase boundary required one or two additional grinding, drypressing, and sintering cycles to attain equilibrium. Weight losses during firing averaged $0.5 \%$, with a maximum of $0.95 \%$. The sintered pellets were reduced in forming gas $\left(4 \% \mathrm{H}_{2}-96 \%\right.$ $\mathrm{N}_{2}$ ) at $400^{\circ} \mathrm{C}$ for $1 \mathrm{~h}$. The pellets were allowed to cool at the natural rate of the furnace while under an atmosphere of forming gas. Powders used for X-ray diffractometry (XRD) were obtained by grinding sintered pellets. Powder XRD (Scintag, Santa Clara, CA) was performed, using $\mathrm{CuK \alpha}$ radiation (40 $\mathrm{kV}, 20 \mathrm{~mA}$ ). Commercial software (Scintag) was used to remove the background and $\mathrm{Cu} K \beta$ contribution from the diffraction patterns. Lattice parameters were calculated with a least- squares averaging program ( $\mathrm{POLSQ}^{*}$ ). Room-temperature electrical conductivities of the as-fired and reduced samples were measured with a spring-loaded four-point probe, using a current source and voltmeter (Models 225 and 197, respectively, Keithley Instruments, Cleveland, $\mathrm{OH}$ ). Excitation currents were in the range of $0.1-20 \mathrm{~mA}$. The conductivity was calculated using the equation ${ }^{14}$

$$
\sigma=\frac{1}{\rho}=\frac{1}{\left(\frac{V}{I}\right) w C\left(\frac{d}{s}\right) F\left(\frac{w}{s}\right)}
$$

where $\sigma$ is the conductivity, $\rho$ the resistivity, $V$ the resulting voltage, $I$ the applied current, $w$ the sample thickness, $d$ the sample diameter, and $s$ the electrode-tip spacing. The functions $C(d / s)$ and $F(w / s)$ are correction factors that account for a finite sample diameter and thickness, respectively. ${ }^{14}$ The bulk density of the pellets was $50 \%-60 \%$ of the theoretical density. The conductivity of a given pellet was divided by its relative density, to give an approximate correction for this variation in sample density.

Diffuse reflectance of the as-fired and reduced samples was measured over a wavelength range of $200-850 \mathrm{~nm}$, using a double-beam spectrophotometer with an integrating sphere (Model Cary 1E with Cary 1/3 attachment, Varian, Palo Alto, CA). Baseline spectra were collected using pressed polytetrafluoroethylene (PTFE) powder compacts (Product No. 04101439-00, Varian) that were placed in the sample and reference beams. Data were collected at a scan rate of $600 \mathrm{~nm} / \mathrm{min}$

FORTRAN program by D. Keszler, D. Cahen, and J. Ibers, Northwestern University, Evanston, IL, 1984.

Table I. List of Samples Prepared

\begin{tabular}{|c|c|c|c|c|c|c|c|}
\hline \multicolumn{3}{|c|}{ Cation concentration } & \multirow[b]{2}{*}[\mathrm{In}]{$/([\mathrm{In}]+[\mathrm{Ga}])$} & \multirow[b]{2}{*}{ Phase(s) present } & \multirow{2}{*}{$\begin{array}{l}\text { Firing } \\
\text { time } \\
\text { (d) }\end{array}$} & \multirow{2}{*}{$\begin{array}{c}\text { Diffuse } \\
\text { reflectance? }\end{array}$} & \multirow[b]{2}{*}{ Color } \\
\hline [Zn] & [In] & [Ga] & & & & & \\
\hline 1 & 0.667 & 1.333 & 0.333 & $\mathrm{Zn} 1(\mathrm{ss})+\operatorname{spinel}(\mathrm{ss})$ & 9 & & \\
\hline 1 & 0.8 & 1.2 & 0.4 & $\mathrm{Zn} 1(\mathrm{ss})+\operatorname{spinel}(\mathrm{ss})$ & 9 & & \\
\hline 1 & 0.9 & 1.1 & 0.45 & $\mathrm{Zn} 1(\mathrm{ss})+\operatorname{spinel}(\mathrm{ss})$ & 9 & & \\
\hline 1 & 0.95 & 1.05 & 0.475 & $\mathrm{Zn} 1$ (ss) & 6 & $x$ & White \\
\hline 1 & 1 & 1 & 0.5 & $\mathrm{Zn} 1$ (ss) & 3 & $x$ & Very light greenish yellow \\
\hline 1 & 1.1 & 0.9 & 0.55 & $\mathrm{Zn} 1$ (ss) & 3 & & \\
\hline 1 & 1.2 & 0.8 & 0.6 & $\mathrm{Zn} 1$ (ss) & 3 & & \\
\hline 1 & 1.25 & 0.75 & 0.625 & Zn1(ss) & 3 & & \\
\hline 1 & 1.3 & 0.7 & 0.65 & Zn1(ss) & 3 & & \\
\hline 1 & 1.333 & 0.667 & 0.667 & $\mathrm{Zn1}(\mathrm{ss})$ & 6 & $x$ & Very light green-yellow \\
\hline 1 & 1.4 & 0.6 & 0.7 & $\mathrm{Zn} 1(\mathrm{ss})+\mathrm{Zn} 2(\mathrm{ss})+\mathrm{In}_{2} \mathrm{O}_{3}(\mathrm{ss})$ & 9 & & \\
\hline 1 & 1.5 & 0.5 & 0.75 & $\mathrm{Zn} 1(\mathrm{ss})+\mathrm{Zn} 2(\mathrm{ss})+\mathrm{In}_{2} \mathrm{O}_{3}(\mathrm{ss})$ & 9 & & \\
\hline 2 & 0.6 & 1.4 & 0.3 & $\mathrm{Zn} 1(\mathrm{ss})+\mathrm{Zn} 2(\mathrm{ss})+\operatorname{spinel}(\mathrm{ss})$ & 9 & & \\
\hline 2 & 0.667 & 1.333 & 0.333 & $\mathrm{Zn} 1(\mathrm{ss})+\mathrm{Zn} 2(\mathrm{ss})+\operatorname{spinel}(\mathrm{ss})$ & 9 & & \\
\hline 2 & 0.7 & 1.3 & 0.35 & $\mathrm{Zn} 2$ (ss) & 6 & $x$ & White \\
\hline 2 & 0.8 & 1.2 & 0.4 & $\mathrm{Zn} 2$ (ss) & 3 & & \\
\hline 2 & 0.9 & 1.1 & 0.45 & $\mathrm{Zn} 2$ (ss) & 3 & & \\
\hline 2 & 1 & 1 & 0.5 & $\mathrm{Zn} 2$ (ss) & 3 & $x$ & Very light greenish yellow \\
\hline 2 & 1.2 & 0.8 & 0.6 & $\mathrm{Zn} 2$ (ss) & 3 & & \\
\hline 2 & 1.333 & 0.667 & 0.667 & $\mathrm{Zn} 2$ (ss) & 3 & & \\
\hline 2 & 1.5 & 0.5 & 0.75 & $\mathrm{Zn} 2$ (ss) & 3 & $x$ & Light green-yellow \\
\hline 2 & 1.6 & 0.4 & 0.8 & $\mathrm{Zn} 2(\mathrm{ss})+\mathrm{Zn} 3(\mathrm{ss})+\mathrm{In}_{2} \mathrm{O}_{3}(\mathrm{ss})$ & 9 & & \\
\hline 3 & 0.5 & 1.5 & 0.25 & $\mathrm{Zn} 3(\mathrm{ss})+\mathrm{Zn} 4(\mathrm{ss})+\operatorname{spinel}(\mathrm{ss})$ & 9 & & \\
\hline 3 & 0.54 & 1.46 & 0.27 & $\mathrm{Zn} 3(\mathrm{ss})+\mathrm{Zn} 4(\mathrm{ss})+\operatorname{spinel}(\mathrm{ss})$ & 9 & & \\
\hline 3 & 0.6 & 1.4 & 0.3 & $\mathrm{Zn3}(\mathrm{ss})$ & 6 & $x$ & White \\
\hline 3 & 0.667 & 1.333 & 0.333 & Zn3(ss) & 3 & & \\
\hline 3 & 0.8 & 1.2 & 0.4 & Zn3(ss) & 3 & & \\
\hline 3 & 0.9 & 1.1 & 0.45 & Zn3(ss) & 3 & & \\
\hline 3 & 1 & 1 & 0.5 & Zn3(ss) & 3 & $x$ & Light greenish yellow \\
\hline 3 & 1.2 & 0.8 & 0.6 & Zn3(ss) & 3 & & \\
\hline 3 & 1.333 & 0.667 & 0.667 & Zn3(ss) & 3 & & \\
\hline 3 & 1.5 & 0.5 & 0.75 & Zn3(ss) & 3 & $x$ & Green-yellow \\
\hline 3 & 2 & 0 & 1 & Zn3(ss) & 3 & $x$ & Dark green-yellow \\
\hline
\end{tabular}


with a data interval of $1.0 \mathrm{~nm}$, a signal band width of $2.0 \mathrm{~nm}$, and signal-averaging time of $0.1 \mathrm{~s}$. Pellets were mounted in a blackened sample mask.

\section{Results and Discussion}

Figures 1(a)-(c) show the lattice constants $a$ and $c$ and the unit-cell volume of the $k=3$ member of the homologous series $\mathrm{InGaO}_{3}(\mathrm{ZnO})_{k}$, as a function of the $[\mathrm{In}] /([\mathrm{In}]+[\mathrm{Ga}])$ ratio. Figures 2(a)-(c) and 3(a)-(c) show the same parameters for the $k=2$ and $k=1$ members, respectively. Figure 4 shows the solubility limits of the $k=1, k=2$, and $k=3$ members, as determined using Vegard's law and Figs. 1(a), 2(a), and 3(a). Table II shows that these limits are in reasonable agreement with the previously determined limits. Figures 1(b) and 2(b)
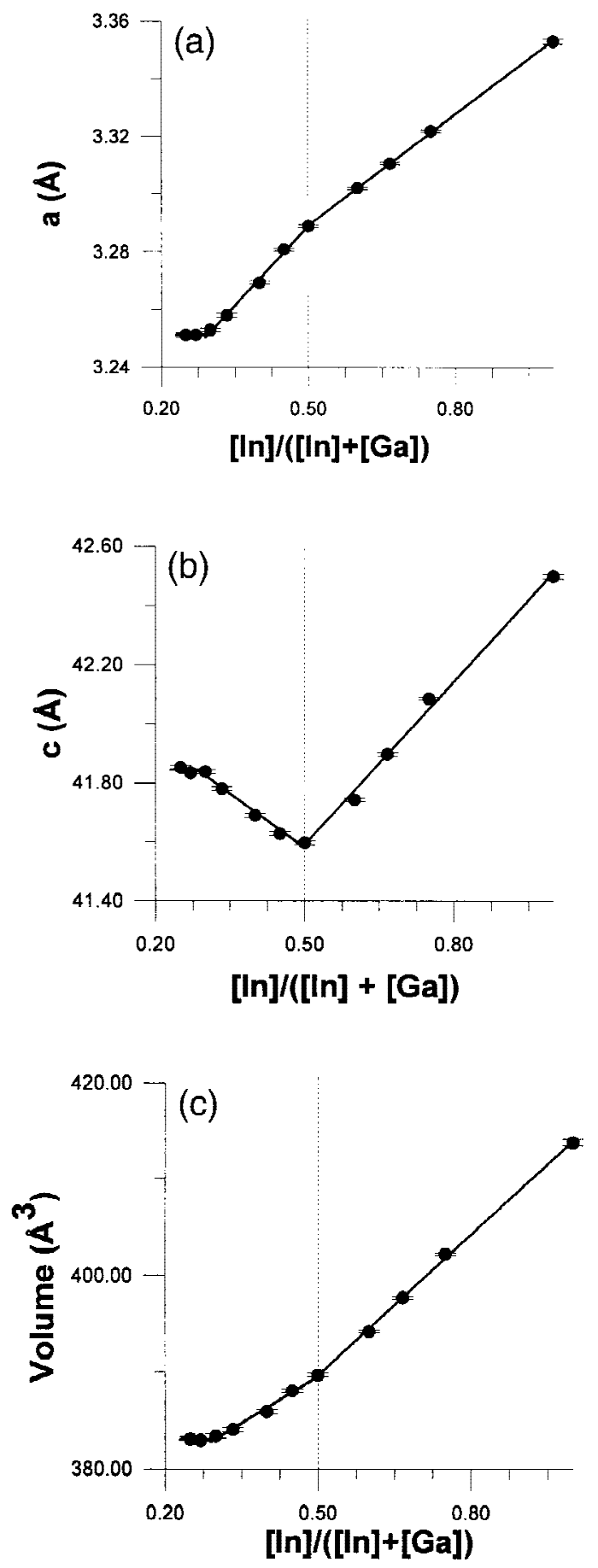

Fig. 1. (a) Lattice parameter $a$, (b) lattice parameter $c$, and (c) unit-cell volume, as a function of indium concentration, for $\mathrm{In}_{1-x} \mathrm{Ga}_{1+x} \mathrm{O}_{3}(\mathrm{ZnO})_{3}$.
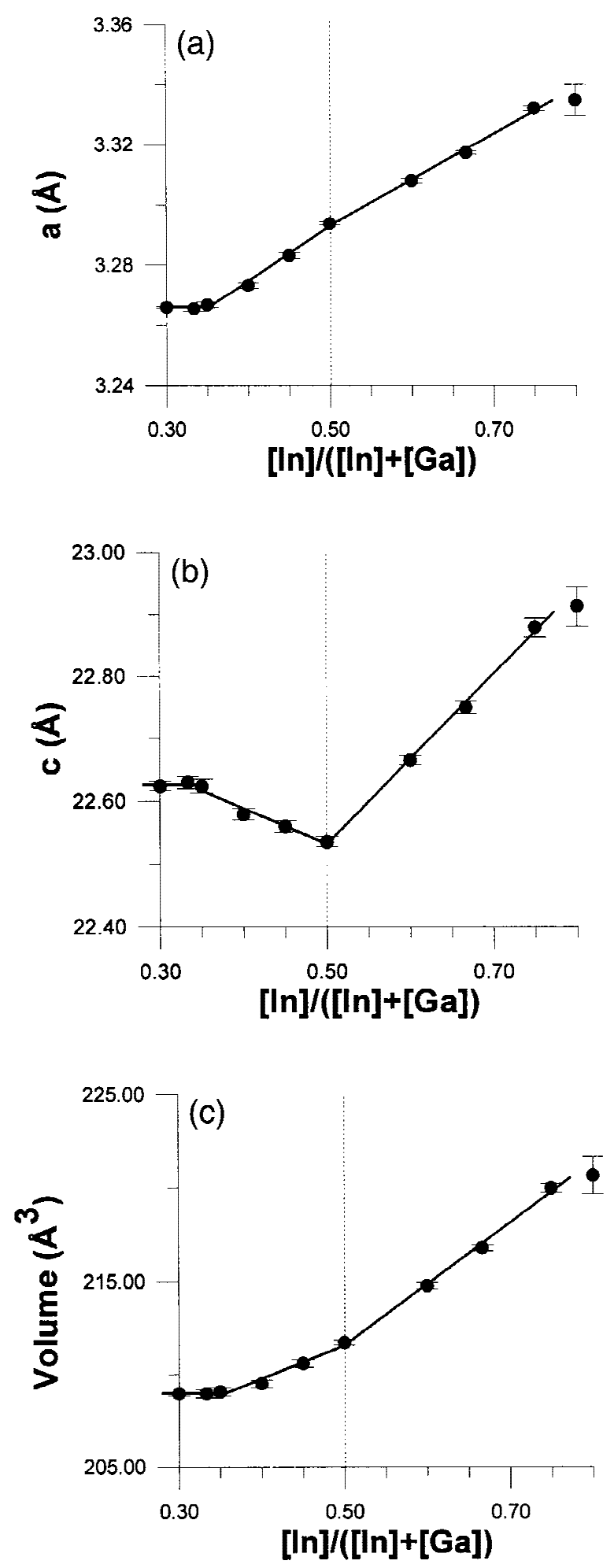

Fig. 2. (a) Lattice parameter $a$, (b) lattice parameter $c$, and (c) unit-cell volume, as a function of indium concentration, for $\mathrm{In}_{1-x} \mathrm{Ga}_{1+x} \mathrm{O}_{3}(\mathrm{ZnO})_{2}$.

show that the lattice constant $c$ first decreases and then increases when the $[\mathrm{In}] /([\mathrm{In}]+[\mathrm{Ga}])$ ratio attains a value of 0.5 for both the $k=3$ and $k=2$ compounds. Figure 3(b) shows a similar trend for the $k=1$ member; however, the initial decrease is not as clearly evident. In all cases, the lattice constant $a$ and the unit-cell volume increase as the amount of added $\mathrm{In}^{3+}$ cations increases. The $\mathrm{Ga}^{3+}$ cation has an atomic radius of 0.55 $\AA(0.055 \mathrm{~nm})$ in fivefold coordination and $0.62 \AA(0.062 \mathrm{~nm})$ in sixfold coordination, whereas the $\mathrm{In}^{3+}$ cation has atomic radii of $0.62 \AA(0.062 \mathrm{~nm})$ and $0.80 \AA(0.080 \mathrm{~nm})$ in fourfold 


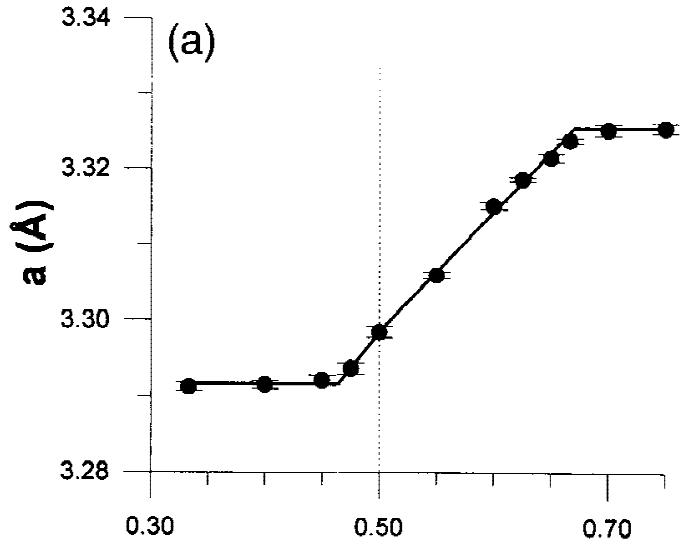

$[\ln ] /([\ln ]+[\mathrm{Ga}])$

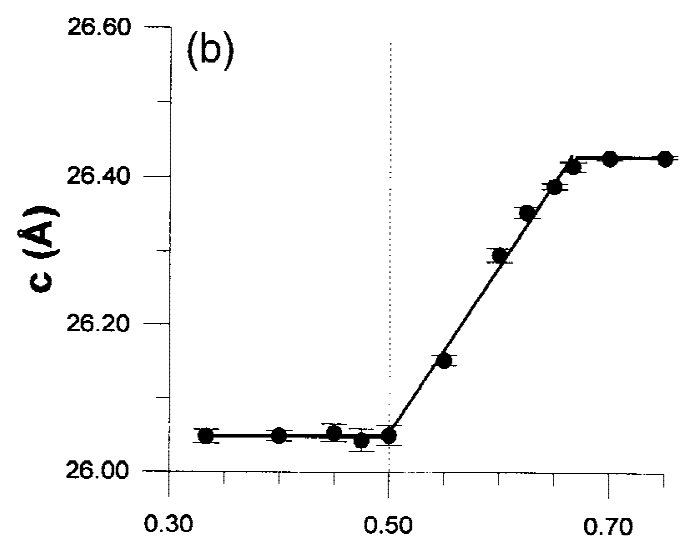

$[\ln ] /([\ln ]+[\mathrm{Ga}])$

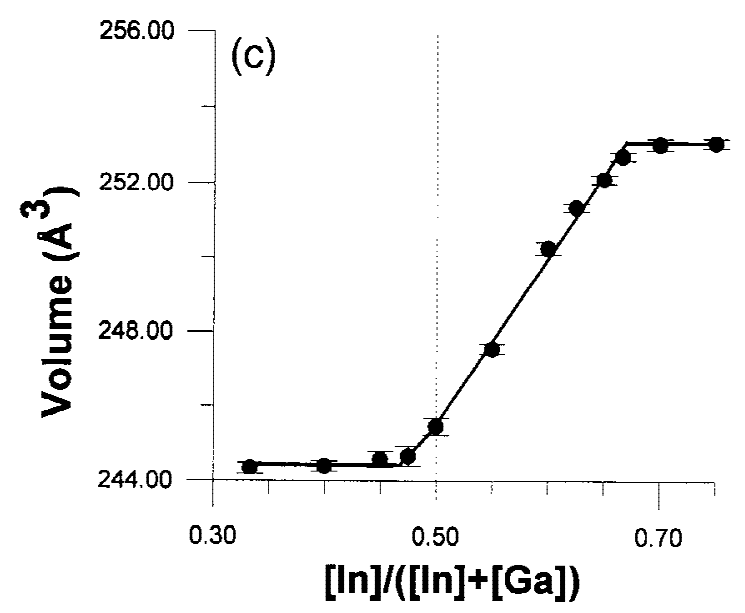

Fig. 3. (a) Lattice parameter $a$, (b) lattice parameter $c$, and (c) unit-cell volume, as a function of indium concentration, for $\mathrm{In}_{1-x} \mathrm{Ga}_{1+x} \mathrm{O}_{3}(\mathrm{ZnO})$.

and sixfold coordination, respectively. ${ }^{15}$ The expansion in the lattice constant $a$ and the unit-cell volume, as a result of the isovalent substitution of the $\mathrm{In}^{3+}$ cation for the $\mathrm{Ga}^{3+}$ cation, is consistent with this information.

The initial contraction in the lattice parameter $c$, which results from this substitution, has been reported previously for $k=2$ and higher members of this series but not for the $k=1$ member. ${ }^{12}$ This unusual behavior was explained by Nakamura et $a .^{12}$ as the $\mathrm{In}^{3+}$ cations filling all the available octahedral sites in the $\mathrm{InO}_{2}^{-}$layers by $[\mathrm{In}] /([\mathrm{In}]+[\mathrm{Ga}])=0.5$. Thereafter, the $\mathrm{In}^{3+}$ cations begin to replace the $\mathrm{Ga}^{3+}$ cations that are located on the $\left(\mathrm{MZn}_{k}\right) \mathrm{O}_{k+1}^{+}$layers. ${ }^{12}$ This phenomenon has been observed in $(\mathrm{Yb}, \mathrm{Eu}) \mathrm{FeO}_{3}(\mathrm{FeO})$, which is isostructural with $\mathrm{InGaO}_{3} \mathrm{ZnO}^{16} \mathrm{Eu}^{3+}$ and $\mathrm{Yb}^{3+}$ cations have ionic radii of 0.947 $\AA(0.0947 \mathrm{~nm})$ and $0.868 \AA(0.0868 \mathrm{~nm})$, respectively, in sixfold coordination. ${ }^{15}$ The substitution of a $\mathrm{Eu}^{3+}$ cation for a $\mathrm{Yb}^{3+}$ cation on an octahedral site causes an expansion in the octahedral layer in the $a$-direction and an expansion in the $a$-dimension of the neighboring $\left(\mathrm{MZn}_{k}\right) \mathrm{O}_{k+1}^{+}$layer, which must be compensated by a contraction in the $c$-direction on this layer, to conserve the average $\mathrm{Fe}-\mathrm{O}$ distance in these layers. ${ }^{16}$ A similar process is believed to be responsible for the contraction in the $c$-direction in the $\mathrm{InGaO}_{3}(\mathrm{ZnO})_{k}$ series. ${ }^{12}$

The existence of the $k=1$ and $k=2$ members at [In]/ $([\mathrm{In}]+[\mathrm{Ga}])=0.5$, but not at $[\mathrm{In}] /([\mathrm{In}]+[\mathrm{Ga}])=1$, together with the change in sign of the slope of the lattice constant $c$ for $k=1,2$ and 3 (Figs. 3(b), 2(b), and 1(b)) at [In]/ $([\mathrm{In}]+[\mathrm{Ga}])=0.5$ suggests that these compositions, $\left(\mathrm{InGaO}_{3}\right)-$ $\mathrm{ZnO}_{k}$, are considered to be the base or constitutive compounds, as opposed to the end members $\operatorname{In}_{2} \mathrm{O}_{3}(\mathrm{ZnO})_{k}$ and $\mathrm{Ga}_{2} \mathrm{O}_{3}(\mathrm{ZnO})_{k}$. This observation has been made previously by Nakamura et al. ${ }^{12}$ The ratio $[\mathrm{In}] /([\mathrm{In}]+[\mathrm{Ga}])=0.5$ is special, because all the $\mathrm{In}^{3+}$ cations are located in $\mathrm{InO}_{2}^{-}$layers and the $\mathrm{Ga}^{3+}$ cations are in the $\left(\mathrm{MZn}_{k}\right) \mathrm{O}_{k+1}^{+}$layers. This ordering will be disrupted if this ratio is disturbed. ${ }^{12}$ These special compositions are marked within the corresponding solubility limits in Fig. 4.

Figure 5 shows a series of diffuse-reflectance spectra for the $k=3$ member of the homologous $\mathrm{InGaO}_{3}(\mathrm{ZnO})_{k}$ series for different $[\mathrm{In}] /([\mathrm{In}]+[\mathrm{Ga}])$ values before and after reduction in the forming gas. Diffuse-reflectance spectra that have been obtained from pellets are analogous to thin-film transmission spectra. ${ }^{17}$ The absorption edge increases (and the band gap decreases) upon reduction in the forming gas. Figure 5 clearly indicates that the peak diffuse reflectance and band gap both increase as the $\mathrm{Ga}^{3+}$ concentration increases. This observation is consistent with the reported direct band gap of 3.55-3.75 $\mathrm{eV}$ for $\mathrm{In}_{2} \mathrm{O}_{3}{ }^{18}$ and a band gap of $4.6 \mathrm{eV}$ for $\mathrm{Ga}_{2} \mathrm{O}_{3} \cdot{ }^{19}$ Figure 6 shows that the trend of increasing band gap (or decreasing absorption edge) with increasing $\mathrm{Ga}^{3+}$ content occurs for $k=1,2$, and 3 . The vertical shift of the curves to higher wavelengths as $k$ increases can be attributed to the increase in the number of $\mathrm{ZnO}$ layers, which have the lowest band gap $\left(3.2 \mathrm{eV}^{19}\right)$ of the three oxides.

Figure 7 shows a plot of the electrical conductivity, as a function of the $[\mathrm{In}] /([\mathrm{In}]+[\mathrm{Ga}])$ ratio, for different $k$ members of the homologous series. The increase in conductivity following reduction is likely due to an increase in carrier concentration. The increase of electrical conductivity with increasing $[\mathrm{In}] /([\mathrm{In}]+[\mathrm{Ga}])$ ratio is consistent with the low conductivity $\left(<10^{-2} \mathrm{~S} / \mathrm{cm}\right)$ of $\mathrm{Ga}_{2} \mathrm{O}_{3}{ }^{20}$ and the substantially higher conductivity $(19.8 \mathrm{~S} / \mathrm{cm})$ of $\operatorname{In}_{2} \mathrm{O}_{3} \cdot{ }^{21}$ The decrease in conductivity with increasing $k$ in the reduced samples implies that conduction is occurring in the octahedral $\mathrm{InO}_{2}^{-}$layers. Although the as-fired samples initially do not seem to follow this trend, the conductivity increases as $k$ decreases in every case where the [In]/ $([\mathrm{In}]+[\mathrm{Ga}])$ ratio is the same in the as-fired samples. This phenomenon is better illustrated in Fig. 8, which shows a plot of the conductivity, as a function of $k$, at fixed $[\mathrm{In}] /([\mathrm{In}]+[\mathrm{Ga}])$ ratios. Again, the reduced specimens have a higher conductivity, because of an increase in carrier concentration.

Another important point is that the slopes of the conductivity curves in Fig. 7 all decrease after the $[\mathrm{In}] /([\mathrm{In}]+[\mathrm{Ga}])$ ratio attains a value of $50 \%$. The decrease in these slopes after a value of $50 \%$ is consistent with our earlier observation that conduction seems to occur primarily in the $\mathrm{InO}_{2}^{-}$layers: up to $50 \%$, the $\mathrm{In}^{3+}$ cations replace the $\mathrm{Ga}^{3+}$ cations in the octahedral $\mathrm{InO}_{2}^{-}$layers, and beyond that point, the $\mathrm{In}^{3+}$ cations replace the $\mathrm{Ga}^{3+}$ cations in the $\left(\mathrm{MZn}_{k}\right) \mathrm{O}_{k+1}^{+}$layers.

Finally, it is possible to infer, from the slope of the $k=2$ 


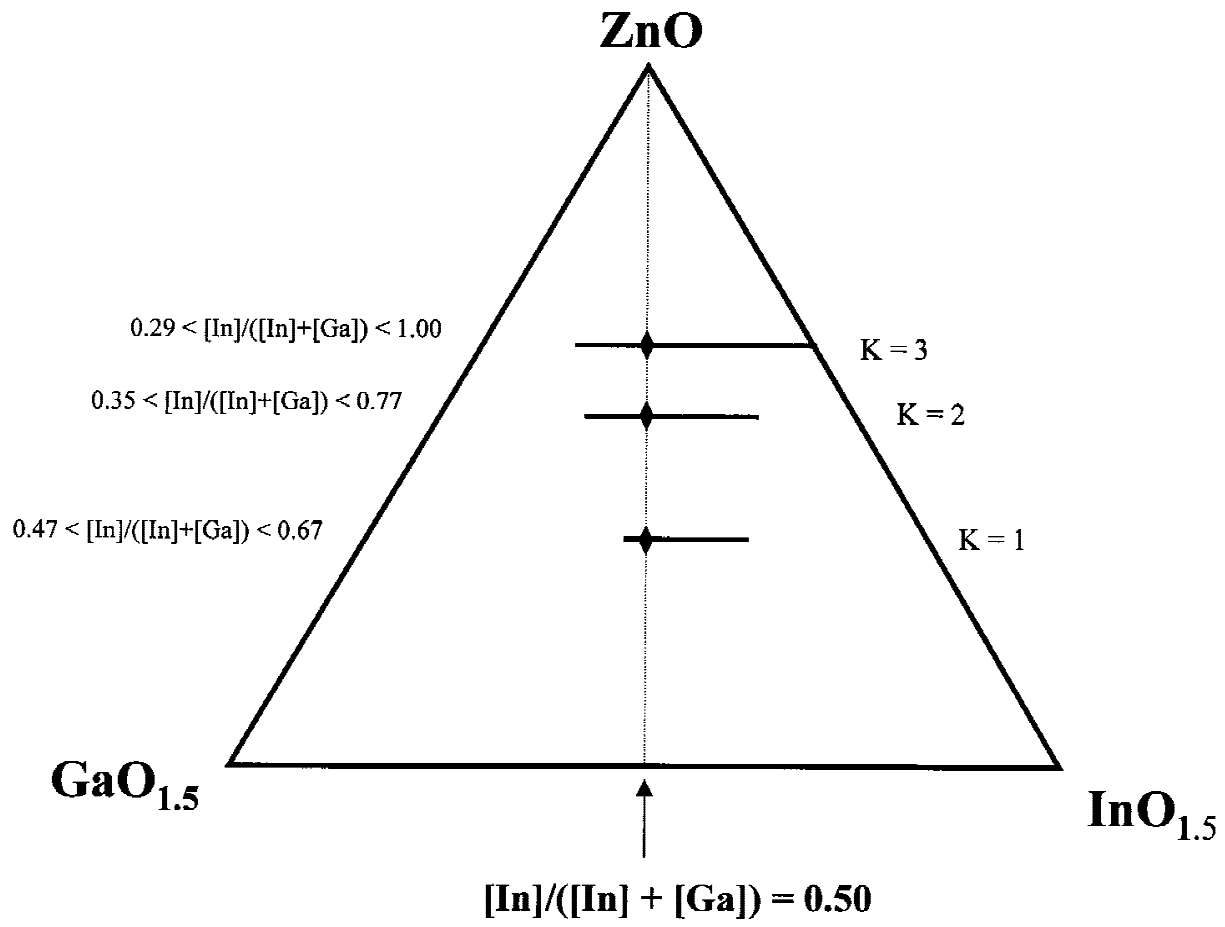

Fig. 4. Solubility limits for the $k=1,2$, and 3 members of $\operatorname{In}_{1-x} \mathrm{Ga}_{1+x} \mathrm{O}_{3}(\mathrm{ZnO})_{k}$.

Table II. Solubility Limits for $k=1,2$, and 3

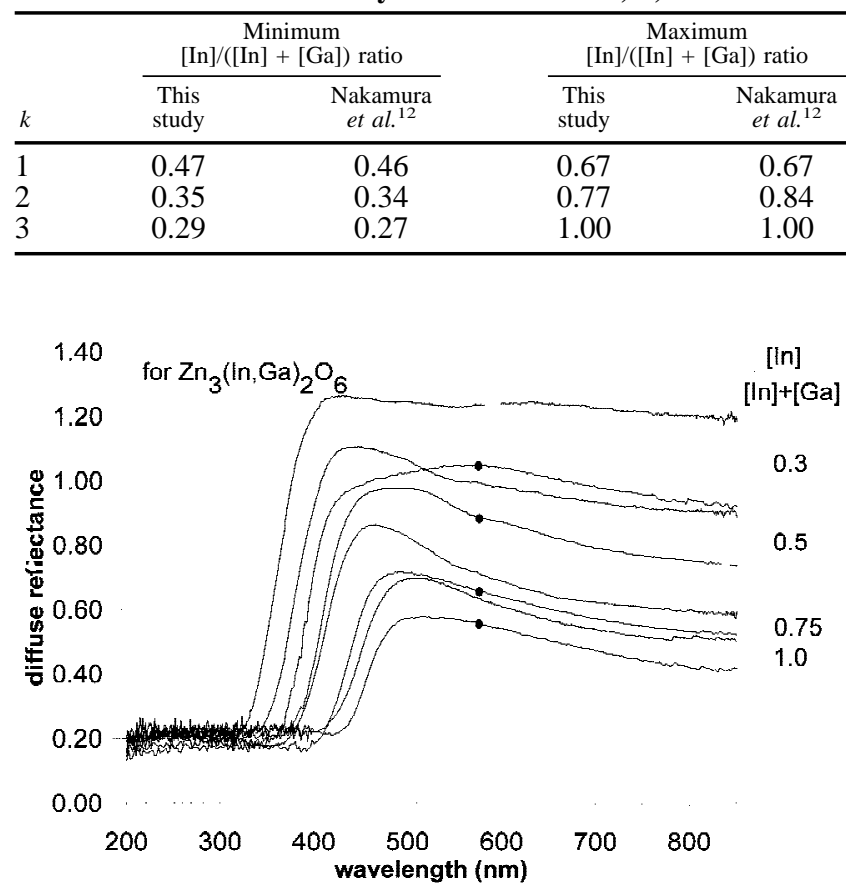

Fig. 5. Diffuse reflectance (percent transmission), as a function of wavelength, at different $[\mathrm{In}] /([\mathrm{In}]+[\mathrm{Ga}])$ values for both $(-)$ as-fired samples and $(\bullet-)$ reduced samples of $\operatorname{In}_{1-x} \mathrm{Ga}_{1+x} \mathrm{O}_{3}(\mathrm{ZnO})_{3}$.

compound in Fig. 7, that if the solid solution could be stabilized out to the $\mathrm{ZnO}-\mathrm{In}_{2} \mathrm{O}_{3}$ binary, a TCO of substantially higher conductivity than the binary $k=3$ member might be formed. Wang et al. ${ }^{22}$ used metal-organic chemical vapor deposition (MOCVD) to deposit $\mathrm{Zn}_{x} \operatorname{In}_{y} \mathrm{O}_{x+1.5 y}$ films (for $x / y=0.08$ 12.0). Such a procedure might be used to produce a highconductivity, metastable $k=2$ compound near the $\mathrm{ZnO}-\mathrm{In}_{2} \mathrm{O}_{3}$ binary. We previously showed that, in the $\mathrm{ZnO}-\mathrm{In}_{2} \mathrm{O}_{3}$ binary, conductivity is a maximum $(270 \mathrm{~S} / \mathrm{cm})$ for the lowest- $k$ mem-

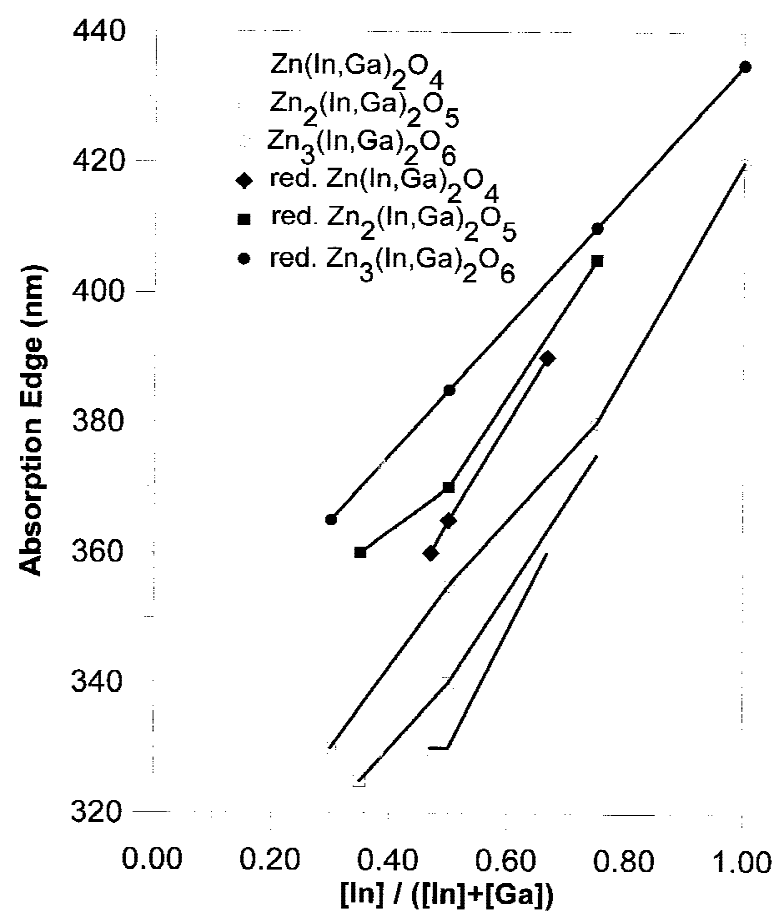

Fig. 6. Absorption edge, as a function of the $[\mathrm{In}] /([\mathrm{In}]+[\mathrm{Ga}])$ ratio, for as-fired and reduced $k=1,2$, and 3 members of the homologous series $\mathrm{In}_{1-x} \mathrm{Ga}_{1+x} \mathrm{O}_{3}(\mathrm{ZnO})_{k}$.

ber $(k=3)$ of the binary homologous series. ${ }^{6}$ The slopes of the $k=1$ and $k=2$ members in Fig. 7 of the ternary homologues indicate that a stabilized $k=2$ compound should have the highest conductivity.

\section{Conclusions}

The solubility limits for $\operatorname{In}_{1-x} \mathrm{Ga}_{1+x} \mathrm{O}_{3}(\mathrm{ZnO})_{k}$ were determined to be $0.47<[\operatorname{In}] /([\mathrm{In}]+[\mathrm{Ga}])<0.67$ for the $k=1$ 


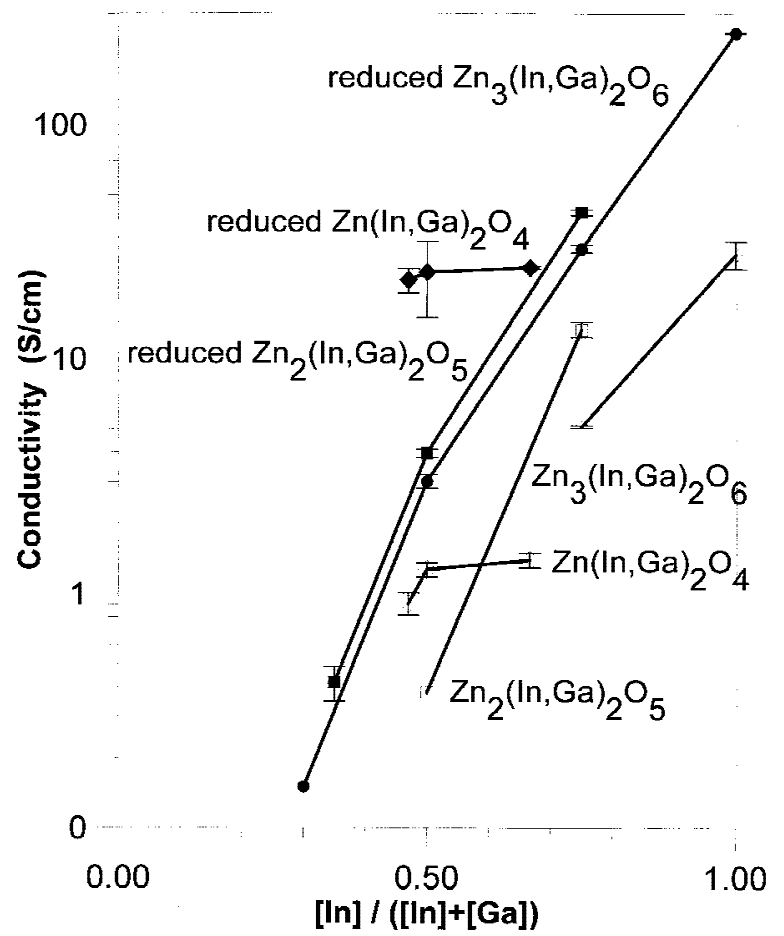

Fig. 7. Conductivity, as a function of the $[\mathrm{In}] /([\mathrm{In}]+[\mathrm{Ga}])$ ratio, for both as-fired and reduced members of the homologous series $\mathrm{In}_{1-x} \mathrm{Ga}_{1+x} \mathrm{O}_{3}(\mathrm{ZnO})_{k}$ for different $k$ values.

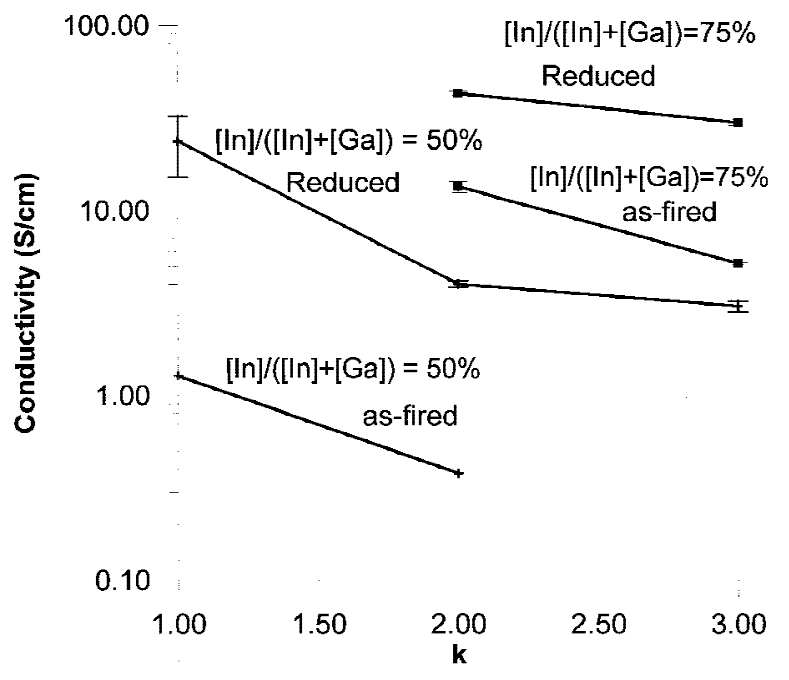

Fig. 8. Conductivity, as a function of $k$, for both as-fired and reduced members of the homologous series $\mathrm{In}_{1-x} \mathrm{Ga}_{1+x} \mathrm{O}_{3}(\mathrm{ZnO})_{k}$ at different $[\mathrm{In}] /([\mathrm{In}]+[\mathrm{Ga}])$ values.

member, $0.35<[\operatorname{In}] /([\mathrm{In}]+[\mathrm{Ga}])<0.77$ for the $k=2$ member, and $0.29<[\mathrm{In}] /([\mathrm{In}]+[\mathrm{Ga}])<1.00$ for the $k=3$ member. These values are in reasonable agreement with previously published results. The electrical conductivity and absorption edge for as-fired and reduced $k=1,2$, and 3 members of the homologous series $\mathrm{InGaO}_{3}(\mathrm{ZnO})_{k}$ were measured. The conductivity increased as the relative concentration of $\mathrm{In}^{3+}$ cations increased and $k$ decreased. The band gap for these materials increased as the relative concentration of $\mathrm{Ga}^{3+}$ cations increased and $k$ decreased. Reduction in the forming gas $(96 \%$
$\mathrm{N}_{2}-4 \% \mathrm{H}_{2}$ ) increased the conductivity and decreased the band gap. A maximum conductivity of $250 \mathrm{~S} / \mathrm{cm}$ was obtained for $k=3$ and $[\mathrm{In}] /([\mathrm{In}]+[\mathrm{Ga}])=1$ after reduction. The minimum absorption edge of $325 \mathrm{~nm}$ was obtained for $k=2$ and [In]/ $([\mathrm{In}]+[\mathrm{Ga}])=0.35$ prior to reduction. Conductivity data indicate that it may be possible to produce a metastable $k=2$ compound near the $\mathrm{ZnO}-\mathrm{In}_{2} \mathrm{O}_{3}$ binary with a higher conductivity than the $k=3$ member on the $\mathrm{ZnO}-\mathrm{In}_{2} \mathrm{O}_{3}$ binary.

Acknowledgments: The authors would like to thank Prof. Carl R. Kannewurf and Jon L. Schindler for the use of their four-point conductivity apparatus.

\section{References}

${ }^{1}$ N. R. Lyman, "Transparent Electronic Conductors"; pp. 201-31 in Proceedings of the Symposium on Electrochromic Materials, Electrochemical Society Proceedings, Vols. 90-92. The Electrochemical Society, Princeton, NJ, 1990.

${ }^{2}$ R. Wang, L. H. L. King, and A. W. Sleight, "Highly Conductive Transparent Thin Films Based on Zinc Oxide,” J. Mater. Res., 11 [7] 1659-64 (1996).

${ }^{3}$ T. Minami, T. Kakumu, and S. Takata, "Preparation of Transparent and Conductive $\mathrm{In}_{2} \mathrm{O}_{3}-\mathrm{ZnO}$ Films by Radio Frequency Magnetron Sputtering," $J$. Vac. Sci. Technol., A, 14 [3] 1704-708 (1996).

${ }^{4}$ T. Minami, H. Sonohara, T. Kakumu, and S. Takata, "Highly Transparent and Conductive $\mathrm{Zn}_{2} \mathrm{In}_{2} \mathrm{O}_{5}$ Thin Films Prepared by RF Magnetron Sputtering," Jpn. J. Appl. Phys., Part 2, 34 [8A] L971-L974 (1995).

${ }^{5}$ J. M. Phillips, R. J. Cava, G. A. Thomas, S. A. Carter, J. Kwo, T. Siegrist, J. J. Krajewski, J. H. Marshall, W. F. Peck Jr., and D. H. Rapkine, "ZincIndium-Oxide: A High Conductivity Transparent Conducting Oxide," Appl. Phys. Lett., 67 [15] 2246-48 (1995).

${ }^{6}$ T. Moriga, D. D. Edwards, T. O. Mason, G. B. Palmer, K. R. Poeppelmeier, J. L. Schindler, C. R. Kannewurf, and I. Nakabayashi, "Phase Relationships and Physical Properties of Homologous Compounds in the Zinc Oxide-IndiumOxide System," J. Am. Ceram. Soc., 81 [5] 1310-16 (1998).

${ }^{7}$ V. H. Kasper, "Neuartige Phasen mit Wurtzitähnlichen Strukturen im System $\mathrm{ZnO}-\mathrm{In}_{2} \mathrm{O}_{3}$," Z. Anorg. Allg. Chem., 349 [3-4] 113-224 (1967).

${ }^{8} \mathrm{P}$. J. Cannard and R. J. D. Tilley, "New Intergrowth Phases in the $\mathrm{ZnO}$ $\mathrm{In}_{2} \mathrm{O}_{3}$ System," J. Solid State Chem., 73, 418-26 (1988).

${ }^{9}$ N. Kimizuka, M. Isobe, and M. Nakamura, "Synthesis and Single-Crystal Data of Homologous Compounds, $\mathrm{In}_{2} \mathrm{O}_{3}(\mathrm{ZnO})_{m}(m=3,4$, and 5), $\mathrm{InGaO}_{3}(\mathrm{ZnO})_{3}$, and $\mathrm{Ga}_{2} \mathrm{O}_{3}(\mathrm{ZnO})_{m}\left(m=7,8,9\right.$, and 16) in the $\mathrm{In}_{2} \mathrm{O}_{3}-$ $\mathrm{ZnGa}_{2} \mathrm{O}_{4}-\mathrm{ZnO}$ System," J. Solid State Chem., 116, 170-78 (1995).

${ }^{10}$ M. A. McCoy, R. W. Grimes, and W. E. Lee, "Planar Intergrowth Structures in the $\mathrm{ZnO}-\mathrm{In}_{2} \mathrm{O}_{3}$ System," Philos. Mag. A, A76 [6] 1187-201 (1997).

${ }^{11} \mathrm{M}$. Nakamura, N. Kimizuka, and T. Mohri, "The Phase Relations in the $\mathrm{In}_{2} \mathrm{O}_{3}-\mathrm{Fe}_{2} \mathrm{ZnO}_{4}-\mathrm{ZnO}$ System at $1350^{\circ} \mathrm{C}$," J. Solid State Chem., 86, 16-40 (1990)

${ }^{12} \mathrm{M}$. Nakamura, N. Kimizuka, and T. Mohri, "The Phase Relations in the $\mathrm{In}_{2} \mathrm{O}_{3}-\mathrm{Ga}_{2} \mathrm{ZnO}_{4}-\mathrm{ZnO}$ System at $1350^{\circ} \mathrm{C}, "$ J. Solid State Chem., 93, 298-315 (1991).

${ }^{13}$ M. Nakamura, N. Kimizuka, T. Mohri, and M. Isobe, "The Phase Relations in the $\mathrm{In}_{2} \mathrm{O}_{3}-\mathrm{Al}_{2} \mathrm{ZnO}_{4}-\mathrm{ZnO}$ System at $1350^{\circ} \mathrm{C}$," J. Solid State Chem., 105, 535-49 (1993).

${ }^{14}$ F. M. Smits, "Measurements of Sheet Resistivities with the Four-Point Probe," Bell Syst. Tech. J., 37 [3] 711-18 (1958).

${ }^{15}$ R. D. Shannon, "Revised Effective Ionic Radii and Systematic Studies of Interatomic Distances in Halides and Chalcogenides," Acta Crystallogr., Sect. A: Found. Crystallogr., A32, 751-67 (1976).

${ }^{16} \mathrm{~N}$. Kimizuka and E. Takayama-Muromachi, "The Systems $\mathrm{R}_{2} \mathrm{O}_{3}-\mathrm{M}_{2} \mathrm{O}_{3}$ M'O"; pp. 283-384 in Handbook on the Physics and Chemistry of Rare Earths, Vol. 13. Edited by K. A. Gschneidner and L. Eyring. Elsevier/North-Holland, New York, 1990

${ }^{17}$ H. G. Hecht, "The Present Status of Diffuse Reflectance Theory"; pp. 1-26 in Modern Aspects of Reflectance Spectroscopy. Edited by W. W. Wendlandt. Plenum Press, New York, 1968.

${ }^{18}$ K. L. Chopra, S. Major, and D. K. Pandya, "Transparent Conductors-A Status Review," Thin Solid Films, 102, 1-46 (1983).

${ }^{19}$ W. D. Kingery, H. K. Bowen, and D. R. Uhlmann, Introduction to Ceramics, 2nd Ed.; p. 155. Wiley, New York, 1976.

${ }^{20}$ G. B. Palmer, K. R. Poeppelmeier, D. D. Edwards, and T. O. Mason, "Systematic Study of Transparent Conductors in the (Zinc,Gallium)-Indium-Tin Oxide Systems"; pp. 309-14 in Materials Research Society Symposium Proceedings, Vol. 508, Flat Panel Display Materials. Edited by T. Fahlen, S. Morozumi, G. Parsons, C. Seager, and C. Tsai. Materials Research Society, Warrendale, PA, 1998.

${ }^{21}$ G. B. Palmer and K. R. Poeppelmeier, "Conductivity and Transparency of $\mathrm{ZnO} / \mathrm{SnO}_{2}$-Cosubstituted $\mathrm{In}_{2} \mathrm{O}_{3}$," Chem. Mater., 9 [12] 3121-26 (1997).

${ }^{22}$ A. Wang, J. Dai, J. Cheng, M. Chudzik, T. Marks, R. Chang, and C. Kannewurf, "Charge Transport, Optical Transparency, Microstructure, and Processing Relationships in Transparent Conductive Indium-Zinc Oxide Film Grown by Low Pressure Metal-Organic Chemical Vapor Deposition," Appl. Phys. Lett., 73 [3] 327-29 (1998). 